Running head: SEQUENCING JUSTICE

\title{
SEQUENCING JUSTICE: A LONGITUDINAL STUDY OF JUSTICE GOALS OF DOMESTIC VIOLENCE VICTIMS
}

Robyn L. Holder and Kathleen Daly

Griffith University, Australia

\begin{abstract}
Authors' Note
Correspondence concerning this article should be addressed to Robyn Holder, Griffith Criminology Institute, Griffith University, Mt Gravatt Campus, 176 Messines Ridge Road, Mt Gravatt, Queensland 4122, Australia. Phone: +61 (0) 737353440 Fax: +61 (0) 737356812 Email: r.holder@griffith.edu.au
\end{abstract}

This is a pre-publication version. The published article is available in The British Journal of Criminology, azx046, https://doi.org/10.1093/bjc/azx046 (published online, 28 September 2017) and see https://academic.oup.com/bjc/issue

(C) Robyn Holder and Kathleen Daly 20 July 2017 


\title{
SEQUENCING JUSTICE: A LONGITUDINAL STUDY OF JUSTICE GOALS OF DOMESTIC VIOLENCE VICTIMS
}

\begin{abstract}
What women as victims of domestic violence want from criminal justice has long interested researchers and advocates. This article foregrounds the ways in which 'justice' matters to victims and how a desire for justice may change over time. We find that victims have multiple justice goals, which are ordered and unfold through the criminal justice process. The goals are directed towards three domains of victim, offender and community; and are influenced by both personal and public interests. Accountability is a threshold goal from which others-punishment, deterrence, rehabilitation or another-may be contemplated. From the perspective of victims, achieving justice is sequencing these goals through hybrid processes with differing degrees of victim participation.
\end{abstract}

\section{Keywords}

Justice goals, justice interests, longitudinal design, domestic violence 
SEQUENCING JUSTICE: A LONGITUDINAL STUDY OF JUSTICE GOALS OF

DOMESTIC VIOLENCE VICTIMS

\section{Funding}

This work was supported by an ANU Miscellaneous Scholarship; a Regulatory

Institutions PhD Scholarship; the Audrey Fagan Post Graduate Scholarship; and an Australian Research Council Discovery Grant [grant number DP130103775].

\section{Acknowledgements}

We are indebted to the women who shared their experiences and to the Domestic Violence Crisis Service, Canberra, for helping make this possible. The first author would also like to thank Peter Grabosky for his guidance and support. 


\section{SEQUENCING JUSTICE: A LONGITUDINAL STUDY OF JUSTICE GOALS OF DOMESTIC VIOLENCE VICTIMS}

What women as victims of domestic violence want from criminal justice has long interested researchers and advocates. Yet women’s preferences are often analysed and understood as competing choices, that is, between a substantive outcome or procedural justice, between conventional or restorative justice, and between private or public justice amongst others (for review, see Daly and Stubbs 2006). The key problem is that evidence on this question is gathered at a single point in time. The desires for justice are more complex, in part, because they unfold over time and in different socio-legal contexts. To understand 'what women want' from criminal justice is better captured with a prospective longitudinal design. This article presents interviews with women on three occasions after their victimization by a male partner or ex-partner, and at different points in the criminal justice process. ${ }^{1}$ It finds that the women have multiple justice goals and prefer to realize them through hybrid processes-a phenomenon we term 'sequencing justice’.

We build on Gromet and Darley’s (2009: 2, 4) insight that people have a 'full range of justice concerns' and 'the ultimate goal of achieving justice' is reached by the progressive realization of sub-goals. Their laboratory research concluded that achieving justice was not accomplished by punishment of the offender alone (2009: 29), but that people were equally concerned with other objectives. In 'real world' research on female victims of domestic violence, studies have provided snapshots of women’s experiences of police (Hirschel and Hutchison 2003; Hoyle and Sanders 2000), prosecution (Hare 2006), and courts (Bell et al. 2011), and their attitudes towards and satisfaction with criminal justice overall (Barata 2007; Erez and Belknap 
1998; Fleury 2002; Smith 2001). However, no study to date has sought to determine women’s expectations of and goals for justice from the beginning to the end of the criminal justice process.

Some have interviewed women on two occasions: a US study identified women’s concerns with how their case was handled in court (Bell et al. 2011), and a Scottish study explored how women engaged the justice system to constrain a violent partner (Lewis et al. 2000). Other US studies have interviewed women on three occasions (Fleury-Steiner et al. 2006; McFarlane et al. 2000). However, all these studies were retrospective. ${ }^{2}$ To date, none has used a prospective design, ${ }^{3}$ which reports women's views and goals as their case moves through a legal process.

Our study is the first to do so. It draws on the routines of criminal justice in an Australian jurisdiction — from reporting to police, to prosecution and through to the criminal court. At each stage in the process, women were asked what they wanted, why their goals were important, and what their preferred processes were to achieve the goals. Their responses were grounded in a multi-dimensional understanding of justice.

\section{Women, violence and justice}

Justice is a complex idea with many different associations (Sen 2009). It is a philosophical and juridical concept and a core social value. Dispensing justice is a primary function of legal institutions. There has been a tendency by researchers, policy makers and activists to assume the aspirations for justice of victims of domestic violence. An early and primary concern critiqued the state's reluctance to enforce the norms of criminal law when confronted with domestic 
violence (Dobash and Dobash 1992). Yet it soon became apparent that criminal justice was not always experienced by women as a benevolent force for good (Snider 1998).

Searches for better or more effective 'alternatives' argued that the 'conflict' between private persons did not belong to the state in the first place (Christie 1977; Mills 1999) and that stronger (or more punitive) criminal justice responses created a dead-end for all concerned (Zehr 1990). The idea of diversion and restorative justice appeared to offer a radical departure (Strang 2002). An emphasis on responding to the harm of victimization was shared by those interested in therapeutic jurisprudence (Wemmers 2008), and reinforced by the conceptual framing of victim viewpoints and preferences as ‘needs' (Herman 2005). The literature debating these approaches in response to gendered violence has become vast (Daly and Stubbs 2006), but in the process, the meanings of justice for victims became lost in searches for responses that were least harmful to them.

Contemporary criminal justice has long been acknowledged as unsupportive of victims, but there is little evidence that healing and restoration are what domestic violence victims seek from state justice (Hare 2006). In their interactions with justice authorities, women victimized by domestic violence are similar to victims of other crimes in desiring to be treated with courtesy and fairness (Van Camp and Wemmers 2013). In addition, domestic violence victims generally initiate police intervention (Felson et al. 2005; Holder 2007). Focusing on women’s agency in initiating the involvement of authorities invites attention to their 'active negotiation and strategic resistance both with their partners and with a range of helping agencies' (Lewis et al. 2000: 180). In this light, women are making ‘justice claims’ (Daly and Stubbs 2006: 19-22). But, claims for what? The waves of debate return to the question of what justice women seek when they mobilize the law following domestic violence. 
A number of scholars suggest that perhaps ‘justice’ is not viewed in a singular manner. As one of us says elsewhere, there are 'intermingled' aspirations for justice that may be meaningful in different ways and at different times (Daly 2000; see also Sen 2009). Part of the problem in knowing what justice women seek is methodological. Most studies ask women for their retrospective opinions (Herman 2005). Others enquire at different levels of analysis. For example, in some studies, women may be asked what justice they sought in their particular case (McGillivray and Comaskey 1999), whereas other studies ask women their general opinion about reform options for justice responses to domestic violence (Nancarrow 2006; Rubin 2010). Part of the problem is also conceptual. Some studies prioritize offender desistance as the objective of criminal justice (Visher et al. 2008) and others emphasize victim concerns (Barata 2007; Hare 2006). The array of justice practices, different experiences of victimization and diverse data collection problems have generated a rich, but confusing scholarship.

In recognising the different ways that justice is understood and its institutions are experienced, researchers and advocates now acknowledge that, as agents, female victims of domestic violence are not limited to identities as 'female' or 'victim' alone. Rather, women are situated in differing and overlapping ways in social and political spaces, and with multiple relationships to authorities. From this perspective, we suggest that women making claims on public authorities for justice hold and project 'interests’ in justice (Holder 2013/2018). The term conveys a broader and less personal justice lens than the term 'needs'. It assumes that victims not only have a relationship with a violent person, but are also in a relation to state authorities. This is not to deny that victims of violence have needs, especially for safety and recovery (Minaker 2001). It is to say that when engaging public justice and looking through a broad justice frame, 
additional aspirations and concerns are engaged, and as a consequence, multifaceted viewpoints emerge.

In responding to these challenges, this study does not attempt to define a 'successful' intervention for women as victims of domestic violence or identify what makes them safer or more satisfied (Holder 2015). Nor does it delineate the contours of a particular model of justice. Rather, it provides a unique empirical exploration of women's preferences—as justice sub-goals (Gromet and Darley 2009)—at the beginning of the regular criminal process and again at its later stages, and the meanings they bring to the idea of justice.

\section{A longitudinal prospective study}

The study’s methods are described more fully elsewhere (Holder 2013/2018, 2016) but in brief, women were interviewed on three occasions following their violent victimization by a male partner or ex-partner. The women, aged over 18 years, were a purposive sample invited to participate in the research through their contact with a domestic violence service. Data collection occurred over four years, from 2009 to 2013. The Time 1 interview took place after the police decided to charge the assailant with a criminal offence. This interview asked each woman why she had turned to the law, with what motivations and expectations, and what she wanted the court to decide. These court options were not hypothetical, but drawn from the study jurisdiction's sentencing legislation. Women were also asked why they wanted those objectives, what they hoped to achieve, and what type of process they would prefer in order to attain those objectives.

The Time 2 interview took place after the case had finished in court. Each woman was asked what she then thought about the decisions and outcomes made by the prosecution and by 
the court, and why she held that view. Each was then asked again about the type of process she would have liked. The time between the first and second interviews varied. The shortest time was two months and the longest was 24 months. The wait time for the second interview depended on when each individual case was finalized at court. The Time 3 interview was conducted six to eight months after the case had finished in court. Each woman was asked what she now thought about justice, in particular, whether justice was done and why. ${ }^{4}$ The longitudinal design facilitated real time attention to women's different engagements with and judgements of law enforcement, prosecution, and court as distinct criminal justice entities.

Longitudinal prospective studies are infrequent, in part, because they are difficult to carry out with both recruitment and retention problems (Plano Clark et al. 2014). These were mitigated by the first author's long-standing relationships with justice and community agencies in the study jurisdiction. ${ }^{5}$ Nonetheless, sample attrition occurred. The study began with 27 participants at Time 1, which reduced to 21 at Time 2 , and 14 at Time 3 (52\% of the original number).

Our analysis of attrition finds no substantial differences (that is, 10 percentage points or more) ${ }^{6}$ for those interviewed in Times 1 and 2 on socio-economic variables and those measuring personal agency, orientations to trust in institutions and in the law, relationship type and longevity, frequency or escalation of violence, or desires to continue the relationship. However, when moving from Time 1 to Time 2 and 3, an increasing share of women initiated the report to the police (67\% to $76 \%$ and $86 \%$ ) and a decreasing share wanted the police to make an arrest (from 44\% to 33\% and 21\%). Differences were evident in the socio-economic profile for those at Time 3, compared to those interviewed once or twice. The Time 3 group was more likely to be tertiary educated and working in a white-collar occupation, ${ }^{7}$ a profile consistent with retention in longitudinal studies of women's health (Young et al. 2006). In addition, the Time 3 group was in 
a shorter-term relationship with the assailant (less than five years); they were less likely to want the court to sentence the offender to community service or to receive a written apology. However, for all three groups, there was consistency in their sentence priority for treatment outcomes.

Our primary focus in this article is on those interviewed twice because it permits us to compare the same group of women over time. However, we shall also present selected findings from the Time 3 interview because they offer reflections on 'the idea of justice' more broadly.

The demographic profile of the 21 women interviewed reflects that of the study jurisdiction, a generally affluent and educated population. The city hosts both federal and state government bureaucracies and four universities. Most women (67\%) were in paid employment, full or part-time; and 38\% of those employed were in white collar jobs. Equal proportions (48\%) earned under AUD \$45,000 and between AUD \$45,000 and \$100,000. ${ }^{8}$ Nearly all were Australian born (86\%) although none was an Indigenous Australian, 43\% had a university degree, and most (67\%) had children living at home.

The 21 participants were unusual in that all the assailants were arrested and their cases proceeded to criminal court; of these, all but two were prosecuted. ${ }^{9}$ Most domestic violence is not reported to authorities in Australia (Cox 2016), a finding similar to that for the United Kingdom (UK) (Walby and Allen 2004), the United States (Felson et al 2005), and Canada (Johnson 2006). When it is, police diversion of domestic violence to 'out of court resolution' may be more widespread than previously thought. For example, every police force in the UK except Scotland was found to divert domestic violence cases away from formal criminal justice resolution, despite a uniform police policy advising against it (Westmarland et al 2017). However, Garner and Maxwell's (2009) review of a number of countries find that 34\% of 
reported offences proceed to prosecution, and when assailants are arrested, 59\% proceed to prosecution, albeit with considerable jurisdictional variation.

At the time of the incident that prompted police involvement, $52 \%$ of the women were in a relationship of five years or more standing. A majority (57\%) were in a relationship with a husband or de facto who was the assailant. For $48 \%$ of the women this was the first time that they had sought help from police, but $29 \%$ had a protection order in place at the time of the incident. A majority (62\%) said their situation was worsening. Before this most recent occasion of reported abuse, all but three of the 21 women had been abused previously by the assailant, with 43\% (of $N=18$ ) saying that the abuse had happened 'quite a few' or 'many' times before.

The experiences and accounts of the women are presented moving from the Time 1 to Time 3 interview. The first section describes 21 women's general expectations of criminal justice at Time 1, and their specific aims and reasons in calling for police assistance. It describes their prospective preferences on the goals they sought from prosecution and the court and through what process. The next gives women's retrospective assessments of the decisions actually reached by prosecution and court personnel at Time 2 . The third section presents the women's reflections about six to eight months after the case was finalized in court, with an analysis of 14 cases at Time 3 .

\section{Time 1: Police Intervention}

\section{Mobilizing law and accountability}

Turning to the law after domestic violence is not an obvious choice for many victims. However,

like other research (Felson et al 2005; Holder 2007), most women initiated the call to police. ${ }^{10}$ All of them agreed with the statement that police viewed what happened to them as serious and 
most felt that 'the community' shared this standpoint. Many expressed a sense of social support in calling police and drew on public discourse that 'domestic violence is a crime'. Indeed, the study jurisdiction has pro-arrest and pro-prosecution policies, which may have influenced women's views and decisions (Novisky and Peralta 2015). For example, Aimee ${ }^{11}$ said she 'knew [it] was illegal, a crime. It was obvious to me ... I just knew that this was not on and that the best way of dealing with it was to go to the police'.

The women's most common aims for police intervention were stopping the violence and a desire to be safe. Others wanted to get help for themselves or simply 'to get out of there'. These are self-regarding motivations. In addition, the women said it was for the offender that they called police. Ursula wanted her husband 'to get help'. Teresa said that she wanted her expartner 'to know he was doing the wrong thing'. This type of language depicts offender-related objectives. Women were also motivated to protect others: their children, significant others and the public. With respect to children, Cathy expressed concern that 'it happened in front of [our son] and I was hit in the stomach and was afraid for the baby. I was not having [our son] grow up thinking it's okay'. ${ }^{12}$ Olivia was 'fearful for the other person' she was now involved with. In all three timeframes the women spoke in different ways about a trilogy of justice interests: for themselves, the offender and their community of others. ${ }^{13}$

Although most women had initiated the call to police, seven wanted an arrest made, five did not, and the rest were unsure or wanted other actions taken. Despite a degree of ambivalence, only five women said that they subsequently asked that charges arising from the incident be dropped. One did so because she felt her husband was mentally unwell, another because she felt shared culpability for the incident, another because she felt the arrest was sufficient to produce 
changes in behaviour, and two because they were emotionally attached to and concerned for the violent person.

Structuring their reasoning were strong views that the abuse was wrong. They used different expressions to say the violence was unacceptable and should not be swept 'under the rug'. The violent person 'needs to wake up' and should 'not get away with it'. They felt the 'truth' should be known; that the violent person 'should know better, know what's right and wrong'. On these points of wrongfulness, women asked that the violent person 'accept responsibility' and 'be accountable for [his] actions'. These words comprised the elements of accountability, a hope that women repeated in their first interview and which grew in later interviews. Offender accountability served as a bridging concept from the situational drive to call the police to stop the violence and women's contemplation of the justice process that lay ahead. Prospective justice goals

All but two women expected that the justice system would be fair, an expectation that was also found in two US studies (Barata 2007; Bell et al. 2011). Women’s specific thinking about outcomes was probed in several ways. Looking ahead to the court process, they were asked what decision they would like the magistrate or judge to make, what sentence outcome they would prefer, and what principles of justice they thought were important to apply to their case. With 17 relevant sentence options in the jurisdiction's legislation and nine possible justice principles, the interview kept definitions as simple as possible. For example, the principle of punishment was described as doing ‘something to punish/discipline/penalize/chastise the person', and the principle of restoration was doing 'something to recognize the harm caused and to help restore all parties’. 
Of the 21 women, most (76\%, $\mathrm{N}=16$ ) wanted the court to render a guilty finding, and its meaning was simple: 'he did it', said Holly. The reason for her preference was 'he'll just keep doing it and think he can get away with it'. Two said they were neither in favour nor against a guilty finding. For the three women who did not want a guilty finding, all indicated that they wanted their relationship with the violent person to continue and they made mitigating comment on his behalf. Roslyn's partner had previously been convicted of assaulting her. She shared a small business with him and wanted her relationship with him to continue. Although she had not wanted an arrest or guilty finding, she hoped to see, at some point, 'an admission of responsibility for his actions'. Of the five who said that they had not wanted the violent person arrested, most said that they favoured a guilty finding.

After stating a preference for a guilty finding, the women indicated the sentence outcome they favoured. They could choose more than one option as 'essential, the highest priority'. Preferences clustered strongly for sentence outcomes that were rehabilitative of the offender, protective of the victim and the community, and which drew on the authority of the court. Least favoured was the imposition of a fine or for the violent person to perform a service for the victim. Then, when asked to specify their first and second priority out of these sentence preferences, women's views sharpened. Of primary importance was that the violent person had some type of treatment: for drugs and alcohol, violence rehabilitation or mental health. Next was to have a custodial sentence of some type imposed: weekend detention, a suspended sentence or full-time custody.

Finally, the women were asked to indicate which justice principle out of nine choices they would like a magistrate or judge to apply to their case. Their answers clustered strongly on the principle of rehabilitation (76\% said it was of 'utmost importance'), and then on principles of 
victim protection and specific deterrence of the offender. While $29 \%$ of women said the principle of restorative justice was of 'utmost importance', most rejected the option of apology, whether made in person or in writing. More women (48\%) thought that an apology was 'undesirable and would make matters worse' than those who thought it was essential (19\%).

In giving reasons for their preferences, women joined their thinking to the justice trilogy of victim, offender and their community of others. Their comments reiterated a desire for accountability and for recognition of the wrongfulness of the perpetrator's behaviour, and unfolded in two ways. Polly's comments are illustrative. First and for herself, Polly wanted to be safe-a self-regarding objective. Then, she went on to emphasize what 'he' needs and her goal for other 'human beings' — the two other objects in the justice trilogy. She said, He definitely needs to be taught that it is absolutely wrong to hurt another human being. When he has paid his price, then there needs to be something in place so he never does it again; and there needs to be things available to help him and to help him be a better person. [Emphasis added]

Polly also emphasized different consequences to the perpetrator for the violent behaviour. Her reasons combined concepts of censure (taught that it is absolutely wrong), punishment (paying a price), deterrence (he never does it again), and rehabilitation (things to help him). Nearly all women in the study voiced their multiple justice goals in this manner: specifying the object and giving the reason. Their goals were multi-directional, and their reasoning reflected different dimensions to justice. Polly’s comments above also reveal an ordering of her multiple goals. They are sequenced in that one follows the other: first censure, then punishment, then deterrence and then rehabilitation. 


\section{Prospective process preferences}

At Time 1, women were also asked through what criminal justice steps they could envisage achieving their multiple goals. They were provided with eight possible resolution pathways (in both visual and written format and as shown in Table 1) to a justice process that lay ahead of them. Different types of participatory activity in the pathways included giving a victim impact statement (VIS) and being part of a restorative opportunity. ${ }^{14}$ The latter was described as an occasion, with a trained facilitator, to discuss with the violent person what happened and what should happen next.

Two groups emerged in the analysis. Four women (19\%) preferred an informal justice process. They wanted the violent person to make an admission to the police, but then wished to see the case diverted from the criminal court process. They did not indicate an interest in the court making a guilty finding. These women wanted their relationship with the violent person to continue, and the reasons they gave for diversion focused on relationship repair. However, at times, their preference was qualified: 'if he hadn’t hit rock bottom and bounced back, I might have a different opinion', one said.

A second group of 17 women (81\%) preferred a formal justice process. Their first preference was for the case to be decided in court with a guilty finding. In this group, one woman wanted her relationship with the violent person to continue, five were unsure or thought 'maybe not', and 10 'definitely' did not want the relationship to continue. After a court finding, this group split into two sub-groups with respect to pathways. One quarter wanted no or minimal participation by them as victim. They wanted the system to 'deal with it' or felt that more involvement from them would 'make matters worse'. However, most wanted some participatory involvement, identifying varied sequence configurations. 
TABLE 1: Women's preferred justice process, $n=21$ at the Time 1 interview

Process options

Number

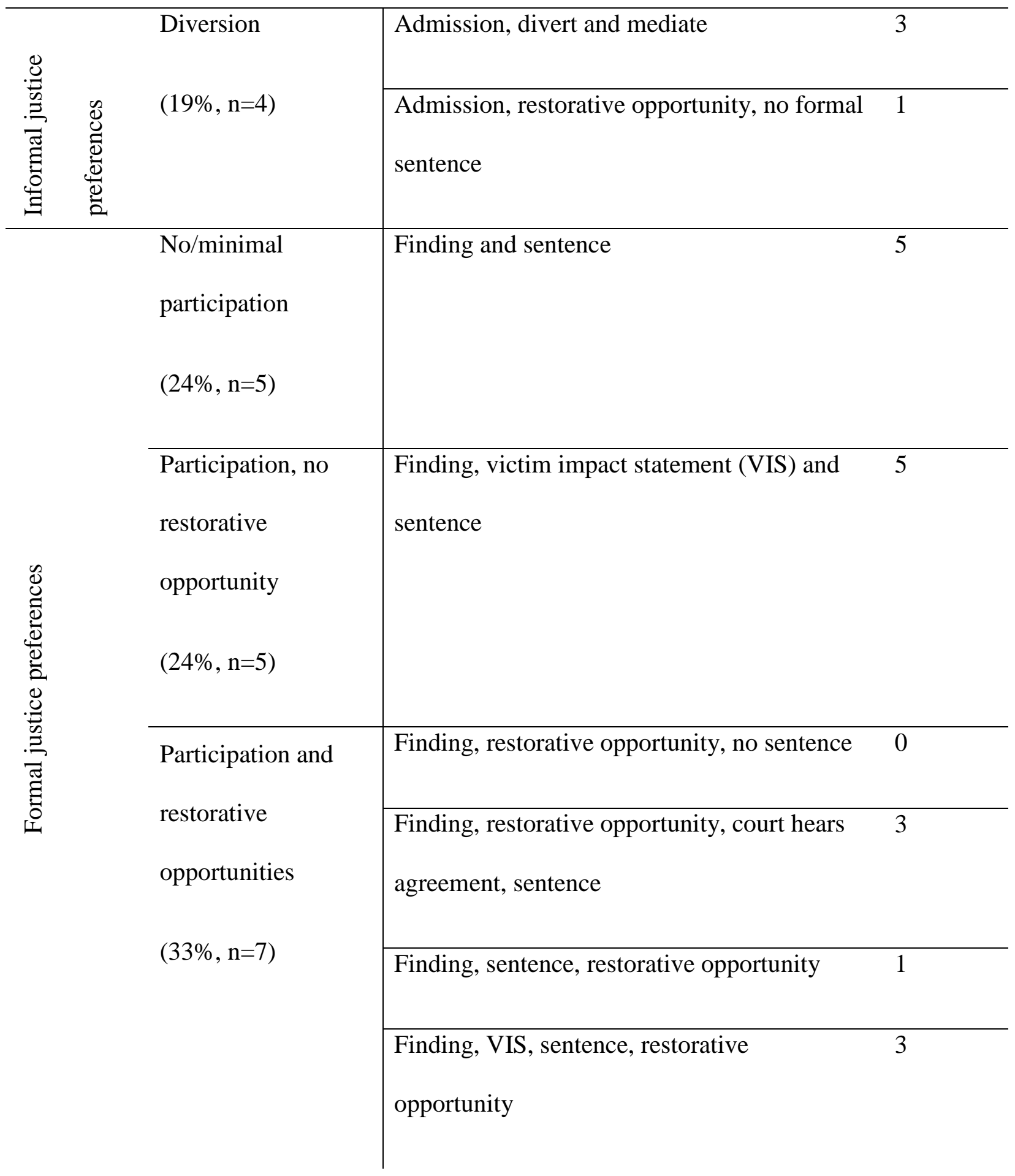


The court's guilty finding was an essential first step for those in the formal justice preference group. Women said that this decision made the perpetrator's culpability clear. They also felt that, after this occurred, they as victims could then deliver information to the court about what to do next and the offender may be more strongly influenced by the court's sentencing decision. Quinn, for example, said, 'the fact that I don't have to be around him and that it's done by someone who is seen to be "the law" so it sends the message to him that what he's done is not acceptable’.

Eight of those who preferred a formal process felt it was also important for the court and the violent person to hear about the impact of the offence on them through a VIS. Janelle said this was 'because I can tell him what [the abuse] has done and how it has made me feel. I couldn't face him without being in the court because we'd just yell at each other'. However, reflection on the possibility of a VIS was not simply about conveying the harm done. Nada, for example, said that

the Magistrate really needs to hear from the victim to make a proper decision. There is a lot lost between what happens and reading something off a paper. If they can read a VIS and ask questions, it would be good. They need to hear the whole history.

The women viewed the VIS as being potentially influential on the decision-maker. Alice said, 'I think what level of impact it [the offence] has made on my life now and at the time should be dealt with accordingly, which should aid their sentence'. Comments such as these show that the women wanted to see dialogue as not only flowing between victim and offender, but also triangulating with an authoritative decision-maker. 
Seven women in the formal justice group preferred a participatory mix, including a restorative opportunity, after the authoritative finding. The reasons for this configuration tended to combine concerns for the violent person as well as for themselves. Karla, for example, said the following:

[My ex-partner's] actively taking responsibility for his actions and being part of deciding what should happen in front of me would be quite healing for me. At the moment he has nothing but hatred and blame for me and I'd like that responsibility to shift. The feeling of his consent to the sentence feels important. The judge can impose it but he can still not own it.

Karla's comment shows an interaction between her private (interpersonal) interests and her desire to see these ratified in a public forum or by a public authority — what we term her public interests. She wanted her ex-partner to face her and take responsibility for his behaviour in private, and at the same time, she believed that his accepting responsibility would deepen when he was sentenced for the wrongful behaviour in the public forum of the court.

Preferences for a process that combined private interests and public authority often came in a flow of reasoning. Olivia described achieving her goals as stepping one to the other by using the terms 'and', 'also', and 'and then'. In response to the question, 'What is it about these particular [resolution] processes or steps that is most attractive to you?', she said:

He's been found guilty and then the chance to come together to talk about the impacts on me, but also to work together about how to make things different in the future. Also for me to highlight the services that could help. These could be agreed and then come back to the court. Both [of us are] able to be heard and be heard at the sentence where our ideas are taken into account at sentence. Both [of us] have a chance to influence the 
sentence. But if you can't, then the judge would make the final sentence. [Emphasis added]

Here plainly we see the language of sequence. Not long after the actual incident and looking ahead, the women at Time 1 envisaged their multiple goals for justice beginning first with an accountability threshold and then moving through varied process steps.

\section{Time 2: After Prosecution and Court}

Thus far, we have presented women's prospective thinking, that is, what they wanted from decision-makers in the future and through what decision-making pathway. What did they think at their second interview after the case had finished? On this occasion, which was between two to four weeks after the court case finished, women were asked what they had wanted from the prosecutor and from the court, and their perspective on the decisions actually made, that is, their retrospective reflections.

Retrospective reflections on justice goals

At Time 2, two more women indicated that they had asked for the charges to be dropped, raising the number from five to seven. The reasons the seven women gave were varied. Three had reconciled or were concerned about the possibility of a gaol sentence, and two mentioned the length of time involved in the process. A further two discussed direct pressures placed on them. Polly, for example, had her tyres slashed after the police charged her ex-partner with assaulting her. She also said, 'I definitely didn't want to testify. I was frightened what would happen from people he knows. I thought there'd be retaliation. I didn't think the system would protect me'. When asked what they had 'mainly' wanted the prosecutor to do, 16 (76\%) indicated preferences for prosecuting all or some of the charges. ${ }^{15}$ The women repeated strongly their 
concern for accountability as a primary driver. For example, when explaining why she wanted the charges to proceed, Karla said, 'because he did the action and if he suffered the consequences, maybe he won’t do it again. It was a serious thing he did'. The women gave similar reasons for the case proceeding as they did in their first interview: they wanted acknowledgement for themselves, some meaningful consequence for the violent person, and protection for others.

Then, asked whether they remained in favour or against the court finding the violent person guilty or not guilty, 18 women (two more than at Time 1) preferred a guilty finding. For the two who changed their minds, both had wanted the relationship to continue at Time 1 and still did so at Time 2. Asked why she now preferred the guilty finding, Aimee said 'because he was guilty. He accepts that'. Roslyn now wanted her partner 'to be accountable for what he did because I [don't] want to be afraid in my own home. If I'm not true to myself, if I give up on my strong sense, then that's not good. It's being true to my values'. These comments give a sense of the weight that the public authority of criminal justice loaned the women.

At this point in the study, all but two cases had been resolved by way of a guilty plea (91\%). If outcome favourability is, in part, 'personally beneficial', in that a personal goal(s) is achieved (Krehbiel and Cropanzano 2000: 340-341), then, given their desire for offender accountability, the women were vindicated by the offender's guilty plea and the court's finding. In addition, they continued to prefer treatment-oriented court outcomes from the first to the second interview. The reasons they gave were overwhelmingly offender-focused, citing the need for measures to stop the violence, to change other harmful behaviours, and for the offender to realize the wrongfulness of his conduct. The actual sentence was known at this stage, with most men sentenced to court orders or bonds 'to be of good behaviour' $(\mathrm{N}=13)$ with eight of these 
additionally subject to probation supervision. Next in frequency was some form of custody (actual, deferred or suspended, $\mathrm{N}=5$ ). For the remaining three, one received community service and two cases received some treatment (violence rehabilitation or drug/alcohol programs) as part of the sentence. Thus, most women received the desired guilty finding but not their preferred sentence. As an example, Teresa said at Time 1 that she preferred the court to sentence her expartner with a violence rehabilitation order and an order to keep away from her. However, he received a 12-month bond to be of good behaviour and no probation supervision. Reflecting on the court outcomes at her second interview, Teresa said that she 'wasn't sure what to expect, but I just wanted him to understand and get the message from the highest authority that what he was doing was wrong, that he had to stop'. The blend of both personal interests (that he 'understand') and the call to 'the highest' public authority is evident in her comment.

Retrospective reflection on participatory opportunities

At this second interview, conducted just after the court case had concluded, the women were asked if they would have liked a 'restorative opportunity' had it been offered. Compared to the first interview in which eight said they would have taken the opportunity, more said they would do so at Time 2 (N=13, 62\%): eight said 'definitely' they would have, and five said 'maybe'. Four (19\%) were unsure, and four would not have done so. Of the 13 who said they would or might have taken up this opportunity, most did not want to continue the relationship with the man.

Analysing the 13 women further, seven said that they would have preferred a restorative opportunity before a finding. Of this group, three had expressed a preference for diversion at the first interview. As one of these, Yvette explained that 'it would make a better understanding for all involved and it might give another idea other than prosecuting-maybe counselling'. Six saw 
the restorative opportunity coming after the finding, or what Miller and Iovanni (2012: 24) term a 'postconviction dialogue'. Holly had not wanted any restorative opportunity at her first interview. She now thought she was 'safer' for a dialogue to be offered after the court finding, after her ex-partner's violent behaviour was constrained and within the confines of public authority.

In describing the potential of a restorative opportunity, the 13 women often spoke of their desire to convey something to the violent person. This included a discussion of the harm to them, the consequences to others, the wrongfulness of the assault, and the desire for a different person or different relationship. None mentioned an apology. Genevieve said she would 'have liked to have gotten him to admit what he was doing was wrong or to see if he could even admit this'. Imogene thought a restorative opportunity could enable her 'to say "ok this is what you did and these are the consequences to me and your son" and to try to get him to understand that there are consequences to others'. In general, the women with some interest in a restorative opportunity saw the potential of the meeting to contribute to the offender's accepting responsibility for his behaviour and its consequences to him and to her as a victim. For a few women, the potential of a restorative opportunity was to get some answers. Xenia had 'niggling questions unanswered'. Roslyn, Teresa and Polly 'wanted to know why'. Polly said, 'it ate away [at me]. It was really because it was just so aggressive.’

For the eight women who were unsure or not interested in a restorative opportunity, half did not want the relationship with the violent person to continue and half were unsure. These women generally wished to keep or extend the distance between themselves and the violent person. Nada said, 'I think I needed to be as removed as possible from the situation. He was in such a bad state that anything I would have done would have inflamed [him]'. For some, concern 
about their safety underlay their caution about a possible restorative interaction. For example, Winona said she wasn’t sure ‘because I don’t really have anything to say to him and maybe I'd be a bit scared he would lash out at me again'. Others commented that the violent person would not have been genuine in a restorative interaction or would have been manipulative, blaming or threatening. Lorraine was unsure about a restorative opportunity. Talking about her ex-partner, she said, 'he’s very good at putting on a front, especially when it comes to guilt. He's a very good actor’. Birgit felt 'it wouldn't have made any difference. We spoke on the phone, and he was blaming me for [his] being in [custody]. Even after three weeks he was blaming me. He’s just got to take responsibility'. Thus, compared to those who saw potential for a restorative opportunity with an offender, the eight who were unsure or saw no potential were sizing up concerns for their own safety and the men's readiness to engage in the process in a constructive and respectful manner, and his readiness to accept responsibility.

\section{Time 3: Six Months after the Court Case Finished}

The Time 3 interviews were conducted six to eight months after the case had finished at court. Recall that compared to the 21 women interviewed twice, the 14 interviewed at Time 3 were of somewhat higher socio-economic status, more likely to have been in a shorter-term relationship with the assailant, and increasingly composed of those who had called the police themselves, but did not want the man arrested. Only two of those who had initially preferred an informal justice process remained at Time 3. Despite sample attrition, the benefits of understanding the views of those at Time 3 outweigh the drawbacks. Specifically, they provide a longer-term reflection of the women's experiences with the criminal justice process and what, if any, subsequent violence had occurred. 
When asked if they had felt involved enough with their case during the criminal justice process: $50 \%$ said they were, $29 \%$ said that they were not and $21 \%$ were unsure. The women were also asked about the 'outcome decisions' made by 'the justice system'; that is, they were asked to give a global reflection about all the decisions not just the sentence, and about the system as a whole and not any specific part. Most (64\%) agreed the decisions reached had been fair. Their answers to other items were more ambivalent. When asked if the decisions were 'deserved' by them as a victim, a third each said yes, no or unsure; and equal proportions agreed (43\%) and disagreed (43\%) that the justice system decisions were what they 'wanted'. These are not overwhelmingly positive evaluations of criminal justice. Nonetheless, the women's original motivation in calling for police assistance was largely achieved: 57\% said there had been no further violence since the case was finalized in court. Over two thirds (79\%) said they felt safe, and $64 \%$ agreed with the statement that 'justice system intervention has had an impact in stopping the violence against me’.

However, when asked if they felt that justice had been done, 57\% agreed. Like their views in Time 2, their reflections on the nature of justice done tended to focus on the offender and how the justice responses did or did not facilitate accountability and change. Repeated in many women's comments (with emphases added here) were hopes for the offender to think about what he had done and to realize a different way to be. Birgit's ex-partner had received eight months’ gaol time although she had preferred treatment for his alcohol use. Even so, of his time in gaol, she hoped 'he's had time to think and realize that his behaviour has to stop'. Janelle had preferred a custodial sentence for her ex-partner although this did not occur. She wanted it to have been 'long enough for him to realize he did wrong'. She went on to say 'when you're on a 
good behaviour bond, you live your life normally. When you are in gaol, you have to sit and think about what you've done’.

Not only did the women want the offender to think about and acknowledge the wrongfulness of the behaviour, they wanted that realization to turn outwards to others. As an example, Finoula had separated from her ex-partner, but she hoped that the conviction had 'planted a seed in his mind not to do this to anyone else'. Holly's ex-partner had been convicted and received a deferred sentence. She did not think that justice had been done in her case, and she referred to herself and her daughter in explaining why. She said, 'justice would be him in a rehab and not being able to contact $u s$ '. Svetlana drew on wider community debate to say that 'if the government is on such a stance about violence against women, [my ex] should have gotten some more. It wasn't his first time and it [the sentence] needs to get harder as it goes along'.

Others were less certain about having achieved victim-related justice goals. Half of the women disagreed with a statement that 'my interests as a victim of violence were looked after by the justice system’. Ursula had successfully petitioned the prosecution not to proceed with the charges against her husband. Ultimately, however, she came to regret this decision and to believe that justice had not been done. While she remained married and living with him, she observed that 'he got the outcome for him, but I haven't. I'm no safer than I was then'. The period of time that had elapsed from the original incident and the Time 3 interview (about a year) had enabled her to speak more directly to her own interests. She said she would have liked to be able to say to her husband, if he had threatened her again, 'don’t forget there's an order [of the court]'. Olivia didn’t 'feel any safer' despite her ex-partner's conviction. She still slept 'with the phone and keys and with the door locked'. She had wanted 'help' for her ex-partner but did not feel that she 'as an individual matter[ed]'. She went on to say that 'victims need to know more and to know 
why. They need better explanations ... a very strong support network including information about the court system'. On the other hand, Aimee agreed that justice had been done, but at the same time noted the difficulties she faced as a victim in the process. She said her partner 'was made to realize the seriousness of his actions' and that the criminal justice consequences 'all had a deep and lasting impact on him’. But, she wryly observed, ‘you’re just dragged along in all this'. These comments reveal a vulnerability felt by victims that is more diffuse than that experienced solely in relation to the offender. Ursula's remark that she 'needed someone just for me [in the justice process]' recognized her aloneness and irrelevance in a system not designed with victims' interests in mind. 'They all listen, but you are no further ahead', she said.

\section{Discussion}

Previous research suggests that between $21 \%$ to 35\% of women who experience physical violence from a partner or ex-partner seek the intervention of criminal justice authorities (Cox 2016; Felson et al 2005; Johnson 2006; Walby and Allen 2004). The women in this study did so because they wanted an end to the violence, and they drew on the authority of the police and courts to help reach this goal. Most achieved this goal and felt safer. However, this was not their only objective. Their claims for justice related to their connection with the violent person and their sense of obligation to others, in addition to themselves as victims. It was for this trilogy of interests that women sought justice. In their view, justice was due to all (Swift 2014).

For most women, justice entailed both procedural and substantive elements. Their reasoning for pursuing justice was instrumental (that is, to stop the violence or change the offending behaviour) and ethical (that is, to protect others or reinforce desirable community values). It interwove private and public interests. The women were nearly unanimous in naming 
accountability of the offender (private interest) as a motivation for mobilizing the law, and that the law hold him to account (public interest). ${ }^{16}$ Not long after police attended the incident and before the case had reached court, most women further sought accountability through a guilty finding and composite sentences that addressed their different goals. While the incident had emotional impacts, only one of the 21 women mentioned 'healing' as an objective and none spontaneously mentioned an interest in the offender's apologising to them. Asked prospectively before the case went to court, a high share of women said that they preferred to reach their goals in a process that relied on the court's guilty finding and then they would consider other participatory steps such as a VIS or a restorative opportunity. It was after guilt had been established, and thus in the shadow of the court's conviction, that more women at their second interview indicated a retrospective willingness to consider a restorative opportunity. They saw it as an occasion for the violent person to 'realize' what he had done, its effects and its wrongfulness. Over time, the women were consistent in seeking a conviction and consistent in other sub-goals of rehabilitation, victim protection, and drawing on the authority of the court to deter future offending. These rested on women's view that the behaviour was wrong, that the violent person was culpable, and that the intention behind the behaviour needed to be stopped. The language women used and the reasons they gave for the justice they desired did not so much change as unfold and deepen over the course of three interviews.

\section{Making sense of justice and sequencing}

It is this process of unfolding and deepening that a prospective longitudinal methodology can reveal. Research on what 'justice’ women claim after domestic violence is often divided into opposing or entirely separate options. These are then studied at a single point in time, commonly 
retrospectively. Such approaches have obscured the fact that victims have varied preferences and concerns, described by Gromet and Darley as ‘justice goals', towards the 'ultimate goal of achieving justice’ (2009: 2). The authors argue that a process of 'controlled reasoning' can generate consideration of multiple goals and multiple targets of those goals (2009: 29). Women’s goals and targets were revealed when they were provided with more than one opportunity to speak about their case over time. They spoke expansively by depicting a conception of justice that was layered and multi-directional. What may initially seem to be contradictory or even changeable thinking is instead sequenced thinking about different targets of an overarching goal of justice, and of the interests with which they are concerned: self, offender, others. Taken together, these interests, sub-goals and reasons constitute what Sen calls 'plural grounding' for justice (2009: 2).

Moreover, interviewing women at the different focal points of police, prosecution and court finalization showed the contingency embedded within their judgements about justice (Skitka et al. 2010). Sub-goals for justice, from the court's guilty finding to various combinations of sentence, are articulated one after the other as a sequence, and may be reached in a sequence. Thus, for example, the court's guilty finding was a crucial marker of accountability that was distinct from sanctions that came with sentencing. Accountability is both a threshold goal and a reference point in the justice process. Moreover, our study shows that the process creates a kind of sequenced architecture in which justice and its sub-goals may be progressively articulated by women and progressively achieved. These spaces and opportunities create the possibility for what Stubbs (2012) has called 'a hybrid approach' to justice for victims of domestic violence. Whereas she emphasises the 'conditions' needed for restorative justice to be ‘safe and effective’ for gendered violence (2012: 213), we emphasise hybridity of 
conventional and innovative processes in which women may be involved. Contemporary criminal justice remains antithetical to this degree of victim participation and articulation. Yet women's interest in participating in different ways and at different occasions with different intents was precisely because a publicly sanctioned criminal justice system had the authority and means to facilitate and deliver (if only incompletely) their multiple goals. If we use the idea of 'the sequencing of justice goals', we are able to see that one set of justice principles or terms need not be privileged over another, nor that one must happen before the other.

Elsewhere, one of us has observed that the youth justice conferencing process can permit time for participants to express multiple justice principles, not just one. As a consequence, 'retributive, restorative, and rehabilitative principles and terms are intermingled, or they may shift in emphasis, depending on the conference phase' (Daly 2000). Our study shows the same for victims of domestic violence in a conventional criminal justice process. Here, however, the time frame is not a 60-minute conference, but a substantially longer time and multiple occasions as a case moves through a criminal process and six to eight months after it concludes. By taking this longer view, we are able to see the idea of justice from a victim's perspective as a sequenced activity comprising distinct layers, not as it is often portrayed, as a oppositional dichotomy. 'Repair or revenge’ (Strang 2002), 'restorative or retributive’ (Zehr 1990), rehabilitation or punishment, among other examples, have promulgated a misleading and distorted understanding of the justice many victims, including those affected by domestic violence, seek in the aftermath of crime. 


\section{References}

BARATA, P. (2007), ‘Abused Women’s Perspectives on the Criminal Justice System’s Response to Domestic Violence', Psychology of Women Quarterly, 31/2: 202-215.

BELL, N., PEREZ, S., GOODMAN, L. and DUTTON, M. (2011), ‘Battered Women’s Perceptions of Civil and Criminal Court Helpfulness: The Role of Court Outcome and Process', Violence Against Women, 17/1: 71-88.

BOYKIN, D., LONDON, M. and ORCUTT, H. (2016), ‘Examining Minority Attrition Among Women in Longitudinal Trauma Research', Journal of Traumatic Stress, 29: 26-32.

CHRISTIE, N. (1977), ‘Conflicts as Property’, The British Journal of Criminology, 17/1: 1-15.

COX, P. (2016), Violence Against Women: Additional Analysis of the Australian Bureau of Statistics' Personal Safety Survey, 2012, ANROWS Horizons: 01.01/2016 Rev. ed. Sydney: ANROWS.

DALY, K. (2000), 'Revisiting the Relationship between Retributive and Restorative Justice’. In H. Strang and J. Braithwaite eds, Restorative Justice: From Philosophy to Practice, 33-54. Ashgate.

DALY, K. and STUBBS, J. (2006), ‘Feminist Engagement with Restorative Justice’, Theoretical Criminology, Special Issue on Gender, Race, and Restorative Justice, 10/1: 9-28.

DOBASH, R. E. and DOBASH, R.P. (1992), Women, Violence and Social Change. Routledge.

EREZ, E. and BELKNAP, J. (1998), 'In Their Own Words: Battered Women's Assessment of the Criminal Processing System's Responses', Violence and Victims, 13/3: 251-268.

FELSON, R., ACKERMAN, J. and GALLAGHER, C. (2005), 'Police Intervention and the Repeat of Domestic Assault’, Criminology, 43/3: 563-588. 
FLEURY, R. (2002), 'Missing Voices: Patterns of Battered Women’s Satisfaction with the Criminal Justice System’, Violence Against Women, 8/2: 181-205.

FLEURY-STEINER, R., BYBEE, D., SULLIVAN, C., BELKNAP, J. and MELTON, H. (2006), ‘Contextual Factors Impacting Battered Women’s Intentions to Reuse the Criminal Legal System', Journal of Community Psychology, 34/3: 327-342.

FORD, D. (1991). 'Prosecution as a Victim Power Resource: A Note on Empowering Women in Violent Conjugal Relationships', Law and Society Review, 25/2: 313-334.

GROMET, D. and DARLEY, J. (2009), 'Punishment and Beyond: Achieving Justice Through the Satisfaction of Multiple Goals', Law and Society Review, 43/1: 1-38.

HARE, S. (2006), 'What do Battered Women Want? Victims' Opinions on Prosecution', Violence and Victims, 21/5: 611-628.

HERMAN, J. (2005), 'Justice from The Victim’s Perspective’, Violence Against Women, 11/5: 571-602.

HIRSCHEL, D. and HUTCHISON, I. (2003), 'The Voices of Domestic Violence Victims: Predictors of Victim Preference for Arrest and the Relationship Between Preference for Arrest and Re-Victimization', Crime \& Delinquency, 49/2: 313-336.

HOLDER, R. (2007), 'Police and Domestic Violence: An Analysis of Domestic Violence Incidents Attended By Police in the ACT and Subsequent Actions’, Research Paper 4, August. Sydney: Australian Domestic and Family Violence Clearinghouse.

HOLDER, R. (2013/2018), Just Interests: Victims, Citizens and the Potential for Justice. PhD thesis. Canberra: The Australian National University. Revised for 2018 publication by Edward Elgar. 
HOLDER, R. (2015), ‘Satisfied? Exploring Victims’ Justice Judgements’. In D. Wilson and S. Ross eds, Crime, Victims and Policy: International Contexts, Local Experiences, 184-213. Palgrave.

HOLDER, R. (2016), 'Untangling the Meanings of Justice: A Longitudinal Mixed Methods Study’, Journal of Mixed Methods Research, Online version, 1-17, DOI:

$10.1177 / 1558689816653308$

HOLDER, R. and CARUANA, J. (2006), Criminal Justice Intervention in Family Violence in the ACT, November. Canberra: Victims of Crime Coordinator.

HOYLE, C. and SANDERS, A. (2000), 'Police Response to Domestic Violence: From Victim Choice to Victim Empowerment', British Journal of Criminology, 40: 14-36.

JOHNSON, H. (2006). Measuring Violence Against Women: Statistical Trends 2006. Ottawa: Minister of Industry.

KREHBIEL, P. and CROPANZANO, R. (2000), 'Procedural Justice, Outcome Favourability and Emotion’, Social Justice Research, 13/4: 339-360.

LEWIS, R., DOBASH, R. P., DOBASH, R. E., and CAVANAGH, K. (2000), 'Protection, Prevention, Rehabilitation or Justice? Women's Use of the Law to Challenge Domestic Violence', International Review of Victimology, 7/1-3: 179-205.

MCFARLANE, J., WILLSON, P., LEMMEY, D. \& MALECHA, A. (2000), 'Women Filing Assault Charges on an Intimate Partner’, Violence Against Women, 6/4: 396-408.

McGILLIVRAY, A. and COMASKEY, B. (1999), Black Eyes All of the Time: Intimate Violence, Aboriginal Women, And the Justice System. University of Toronto Press. 
MILLER, S. and IOVANNI, L. (2013), ‘Using Restorative Justice for Gendered Violence:

Success with a Postconviction Model’, Feminist Criminology, 20/10: 1-22.

MILLS, L. (1999), ‘Killing Her Softly: Intimate Abuse and the Violence of State Intervention’, Harvard Law Review, 113/2: 550-613.

MINAKER, J. (2001), ‘Evaluating Criminal Justice Responses to Intimate Abuse Through the Lens of Women's Needs', Canadian Journal of Women and the Law, 13: 74-106.

NANCARROW, H. (2006), 'In Search Of Justice for Domestic and Family Violence: Indigenous and Non-Indigenous Australian Women’s Perspectives', Theoretical Criminology, 10/1: 87106.

NOVISKY, M. and PERALTA, R. (2015), 'When Women Tell: Intimate Partner Violence and the Factors Related to Police Notification’, Violence Against Women, 21/1: 65-86.

PLANO CLARK, V., ANDERSON, N., WERTZ, J., ZHOU, Y., SCHUMACHER, K. and MIASKOWSKI, C. (2014), 'Conceptualizing Longitudinal Mixed Methods Designs: a Methodological Review of Health Sciences Research', Journal of Mixed Methods Research, Online version, 1-23, DOI: 10.1177/1558689814543563

RUBIN, P. (2010), ‘A Community of One’s Own? When Women Speak to Power About Restorative Justice’. In J. Ptacek, ed, Restorative Justice and Violence Against Women, 79104. Oxford University Press.

SEN, A. (2009), The Idea of Justice, The Belknap Press of Harvard University Press.

SKITKA, L., ARAMOVICH, N., LYTLE, B. and SARGIS, E. (2010), 'Knitting Together an Elephant: An Integrative Approach to Understanding the Psychology of Justice Reasoning’ 
In R. Bobocel, A. Kay, M. Zanna, and J. Olson, eds, The Psychology of Justice and Legitimacy: The Ontario Symposium (Volume 11), 1-26. Psychology Press.

SMITH, A. (2001), 'Domestic Violence Laws: The Voices of Battered Women', Violence and Victims, 16/1: 91-111.

SNIDER, L. (1998), ‘Towards Safer Societies: Punishment, Masculinities and Violence Against Women’, British Journal of Criminology, 38/1: 1-39.

STRANG, H. (2002), Repair or Revenge: Victims and Restorative Justice. Clarendon Press.

STUBBS, J. (2012), 'Justice for Gendered Violence: What does Restorative Justice Offer?' In J. Bolitho, J. Bruce and G. Mason, eds, Restorative Justice: Adults and Emerging Practice, 194-213. Sydney Institute of Criminology.

SWIFT, A. (2014), Political Philosophy: A Beginners' Guide for Students and Politicians, $2^{\text {nd }}$ edition, Polity Press.

VAN CAMP, T. and WEMMERS, J. (2013), 'Victim Satisfaction with Restorative Justice More than Simply Procedural Justice', International Review of Victimology, 19/2: 117-143.

VISHER, C., HARRELL, A., NEWMARK, L. and YAHNER, J. (2008), 'Reducing Intimate Partner Violence: An Evaluation of a Comprehensive Justice System-Community Collaboration', Criminology and Public Policy, 7/4: 495-523.

WALBY, S. and ALLEN, J. (2004), Domestic Violence, Sexual Assault and Stalking: Findings from the British Crime Survey, Home Office Research Study 276, Home Office.

WEMMERS, J. (2008), 'Victim Participation and Therapeutic Jurisprudence’, Victims and Offenders, 3/2-3: 165-191. 
WESTMARLAND, N., JOHNSON, K. and McGLYNN, C. (2017), 'Under the Radar: The Widespread Use of “Out Of Court Resolutions” in Policing Domestic Violence and Abuse in the United Kingdom', British Journal of Criminology, 1-16, doi:10.1093/bjc/azx004

YOUNG, A., POWERS, J. and BELL, S. (2006), 'Attrition in Longitudinal Studies: Who Do You Lose?', Australian and New Zealand Journal of Public Health, 30/4: 353-361.

ZEHR, H. (1990), Changing Lenses: A New Focus for Criminal Justice. Herald Press. 
${ }^{1}$ In this study, domestic violence is defined as intimate partner violence, in which a woman was victimised by a male partner or ex-partner.

${ }^{2}$ McFarlane et al. (2000) interviewed women at Time 1 when they intended to file assault charges. The article discusses retrospective findings at Time 2.

${ }^{3}$ Ford (1991) used a limited prospective design in a study of 25 women who initially sought prosecution; he subsequently interviewed 13 to determine why they had 'dropped charges' before the case went to court.

${ }^{4}$ The average time for each interview at all three interview points was 65 minutes.

${ }^{5}$ From 1994 to 2011, the first author worked as a statutory victim advocate in the study jurisdiction and led a coordinated community and criminal justice response to domestic violence (Holder and Caruana 2006).

${ }^{6}$ With small sample sizes and non-independent samples, we did not carry out tests of statistical significance, but instead identified when differences were 10 percentage points or greater on the variables.

${ }^{7}$ They were also more likely to speak another language at home in addition to English, a measure often associated with increased attrition of 'minorities' (Boykin et al. 2016). For this sample, however, bilingualism was associated with having a tertiary education.

${ }^{8}$ One woman earned between $\$ 100,000$ and $\$ 250,000$. The 2011 average gross individual income of a full-time employee in Australia was \$53,000 (approximately GBP 34,000 or USD 54,000, using the 2011 average exchange rate).

${ }^{9}$ In these two cases the prosecution had offered no evidence and the charges were dismissed in court. For both, the women made strong representations to prosecution to drop the charges: one 
because she believed her husband was mentally unwell and the other because of particular circumstances that led to the violence.

${ }^{10}$ Sixteen (76\%) of those interviewed twice said that they had initiated the call to police themselves. Of the five who did not, two said that they supported the report being made, two were unsure and one did not want the report made.

${ }^{11}$ All names used are pseudonyms.

${ }^{12}$ Although 14 of the 21 women had children living with them at the time of the incident, just four of the 14 (29\%) mentioned children in their reasons for calling the police.

${ }^{13}$ Gromet and Darley call these three ‘justice targets’ (2006: 2).

${ }^{14}$ In the study jurisdiction, there were a number of legislated paths for the resolution of a criminal offence. At the time of the study, one of these was a restorative conference for youth matters (if the alleged offender made an admission or was convicted) but not for adults and not for domestic violence. Despite this, pre-admission or conviction options for a restorative encounter were put to the study participants. They were advised that these options were not actually available to them and that they were being asked in order to gain some idea of the degree of interest.

${ }^{15}$ There is a surface inconsistency between seven women saying they had asked for charges to be dropped and 16 saying they wanted all or some of the charges prosecuted. However, the first is a response to an open question about an action undertaken 'at any time' during the prosecution process. The second derives from closed response options that focused narrowly on 'when the prosecution was dealing with your case'.

${ }^{16}$ Public interest is defined as that which is of common concern to the general populace. It is often separated from a private interest. Women's comments showed private and public interest as 
interweaving and mutually defining. The example of offender accountability shows private interest for it and public interest that it is secured as being two sides of the same coin. Likewise, for individuals to live free of violence is an objective that is a private and a public interest. 